\title{
Molecular diagnostics in the management of chronic hepatitis C: key considerations in the era of new antiviral therapies
}

\author{
Bryan Cobb*, Gabrielle Heilek', Regis A Vilchez ${ }^{2}$ \\ From Third Workshop of the HCV Study Group in the Calabria Region \\ Catanzaro, Italy. 04 October 2013
}

\begin{abstract}
Molecular tests that detect and/or quantify HCV RNA are important in the diagnosis and management of patients with chronic hepatitis $\mathrm{C}(\mathrm{CHC})$ undergoing anti-viral therapy. The primary goal of anti-HCV therapy is to achieve a sustained virologic response (SVR) defined as "undetectable" Hepatitis C Virus (HCV) RNA in the serum or plasma at 12 to 24 weeks following the end of treatment.

HCV RNA viral load (VL) monitoring is used to guide treatment duration where decisions can be made on-therapy and to determine whether or not to stop therapy. In addition, clinicians determine treatment regimen and duration based on the HCV genotype (1-6) as well as the kinetics of HCV RNA levels.

As direct acting antivirals (DAA) have revolutionized hepatitis $C$ treatment, they have also lead to new HCV RNA VL result interpretations. Further, the clinical decisions were different for pegylated-interferon/ribavirin (PEGa/RBV)+ boceprevir or telaprevir-containing regimens approved in 2011 (e.g. one requiring an additional 4 week "lead-in" with PEG $\alpha / R B V$ ), each having different HCV RNA values for futility rules, created complexity in clinical decisions. The future pegylated-interferon free DAA- regimens promise significantly improved cure rates along with fixed durations and simpler treatment rules. The intent of this article is to discuss the role of HCV RNA real-time PCR tests used in the management of $\mathrm{CHC}$ patients in the past and how this is likely to change in the era of interferon free DAA regimens.
\end{abstract}

\section{Background}

Chronic HCV (CHC) infection is a global public-health problem, with approximately 170 million persons chronically infected [1] who are at an increased risk of morbidity and mortality [2] due to liver cirrhosis, hepatocellular carcinoma (HCC), and extra-hepatic complications that develop. The incidence of cirrhosis and HCC is projected to dramatically increase over the next decade in certain populations such as the U.S. "baby boomer" birth cohort.

With the development of interferon free, all oral, potent antiviral agents with less adverse effects, the need for screening individuals and successfully treating at-risk $\mathrm{CHC}$ patients becomes increasingly more important and possible.

\footnotetext{
* Correspondence: bryan.cobb@roche.com
}

${ }^{1}$ Roche Molecular Systems Inc., Pleasanton, California, USA

Full list of author information is available at the end of the article

\section{New screening recommendations}

The CDC has previously recommended routine $\mathrm{HCV}$ screening for persons most likely infected with $\mathrm{HCV}$ based on the known epidemiologic risk factors [2] and has published guidelines for laboratory testing using HCV antibody and HCV RNA assays [3]. In 2012, the $\mathrm{CDC}$ amended testing recommendations to include onetime HCV testing for all persons born between 1945 and 1965 ("baby boomers") in the U.S. [3].

\section{The new role for HCV RNA tests in the aid in diagnosis of CHC patients}

Screening for hepatitis $\mathrm{C}$ starts with anti-HCV antibody. The OraQuick HCV Rapid Antibody Test (OraSure Technologies) is a rapid assay for the presumptive detection of $\mathrm{HCV}$ antibody in finger stick capillary blood and venipuncture whole blood [4]. In the U.S., 
this test is approved for use in doctor's offices or clinics that able to use laboratory-based IVD tests [3]. Rapid tests are also available in Europe as well as other parts of the world.

The Recombinant Immunoblot Assay (RIBA) HCV 3.0 Strip Immunoblot Assay (Novartis Vaccines and Diagnostics) that was previously recommended for supplemental testing of blood samples after initial HCV antibody testing is no longer available or recommended.

In 2013, the recommendations were updated for supplementary testing whereby the diagnosis of a current $\mathrm{HCV}$ infection (a positive antibody test) should be confirmed by using a NAT test (Figure 1). This is because an anti-HCV antibody test result can be positive in patients who were previously infected with HCV but have spontaneously cleared infection and are no longer viremic. HCV RNA tests can detect the presence of an active HCV infection. In clinical practice guidelines, using a sensitive molecular method (LLOD $<15 \mathrm{IU} / \mathrm{mL}$ ) is recommended for the diagnosis of acute hepatitis and CHC [4]. However, it's important to note that currently there are no real-time PCR HCV RNA viral load monitoring tests that have been reviewed or approved by any regulatory agencies, including the FDA that have a diagnostic intended use claim supporting these recommendations.

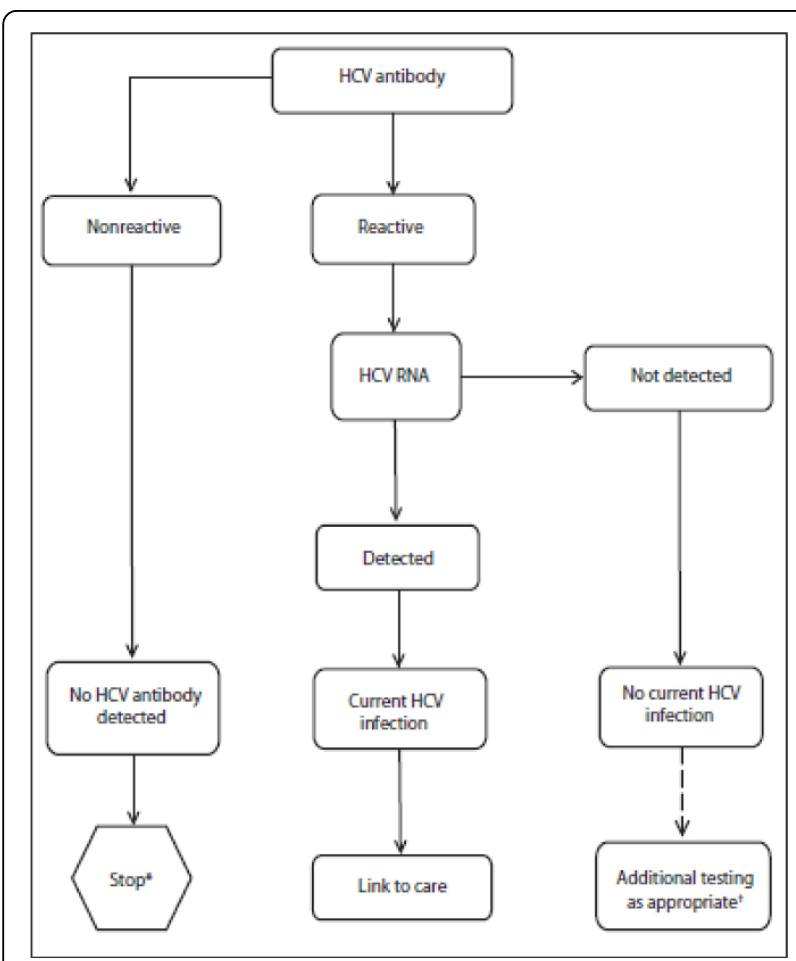

Figure 1 Centers for Disease Control and Prevention recommendation: testing sequence for identifying hepatitis $C$ virus infection

\section{Significance of VL monitoring}

Measurement of HCV RNA is essential for measuring an active infection at baseline, during treatment, at the end of treatment, and for detecting relapse after stopping antiviral therapy (e.g. 12 or 24 weeks later). Absence of viral replication as measured in the bloodstream 3 or 6 months after an antiviral treatment regimen indicates the patient is cured.

\section{Current molecular methods}

A variety of molecular methods have been used to manage $\mathrm{CHC}$ patients. The majority of tests that are used by routine clinical laboratories are based on real-time PCR technologies which quantify HCV RNA during the exponential phase of amplification, with greater sensitivity and a broader linear dynamic range ( 10 to $\left.10^{8} \mathrm{IU} / \mathrm{mL}\right)$. There are several HCV RNA commercial, real-time PCR tests that are available (Table 1).

The COBAS ${ }^{\circledR}$ AmpliPrep / COBAS ${ }^{\circledR}$ TaqMan $^{\circledR}$ HCV Quantitative and Qualitative Test, version 2.0 (TaqMan ${ }^{\circledR}$ HCV Test, v2.0) (Roche Molecular Systems) uses a magnetic silica bead-based automated RNA extraction on the COBAS AmpliPrep platform followed by HCV target specific (5' UTR) amplification and detection performed on the COBAS TaqMan thermal cycler. The assay is approved as a FDA-IVD and CE-IVD quantitative test and as a CE-IVD qualitative test. Both the quantitative and qualitative tests use a dual probe approach where two fluorescently labeled hydrolysis probes simultaneously detect amplicon, providing broader detection and quantification of rare genotype 4 sequences [5,6]. HCV RNA titer is calculated using a competitive quantitative standard, obviating the need for the laboratory to perform calibrations. Reagents are stored at $2-8^{\circ} \mathrm{C}$. A manual version, the COBAS ${ }^{\circledR}$ Taq$\mathrm{Man}^{\circledR}$ Test v2.0 for use with the High Pure System (the HP-TaqMan HCV, v2.0) (Roche Molecular Systems), which instead uses a column-based manual extraction is also available. This test has been predominantly used in the clinical trials for currently approved DAA-interferon containing regimens.

The Abbott RealTime HCV assay (Abbott Molecular) uses an automated, magnetic particle-based nucleic acid extraction on the m2000sp platform followed by a manual sealing of the reaction plate to prepare it for $\mathrm{HCV}$ target specific amplification and detection on the m2000rt platform. To detect the HCV RNA target, a DNA probe with a covalently linked fluorescent moiety and a covalently linked quenching moiety is used. Since a noncompetitive internal control (derived from a pumpkin gene) is used, the laboratory is required to perform lot-specific calibrations. Reagents must be shipped and stored frozen [7]. 
Table 1 Commercially available quantitative real-time PCR-based hepatitis C virus RNA assays

\begin{tabular}{|c|c|c|c|c|c|c|}
\hline Assay & Vendor & Technology (target region) & $\begin{array}{c}\text { IVD } \\
\text { Approval } \\
\text { Status }\end{array}$ & $\begin{array}{c}\text { Dynamic } \\
\text { Range } \\
\text { (IU/mL) }\end{array}$ & $\begin{array}{l}\text { LLOQ } \\
(\mathrm{IU} / \mathrm{mL})\end{array}$ & $\begin{array}{l}\text { LLOD* } \\
(\mathrm{IU} / \mathrm{mL})\end{array}$ \\
\hline $\begin{array}{l}\text { COBAS }^{\circledR} \text { Ampliprep/ } \\
\text { COBAS }^{\circledR} \text { TaqMan }{ }^{\circledR} \text { V2.0 Test }\end{array}$ & $\begin{array}{l}\text { Roche Molecular } \\
\text { Systems }\end{array}$ & Real-time PCR, (5'UTR) & FDA, CE & $\begin{array}{l}15 \text { to } \\
1.00 \times 10^{8}\end{array}$ & 15 & 15 \\
\hline $\begin{array}{l}\text { COBAS }^{\circledR} \text { TaqMan } \\
\text { High Pure System Test, v2.0 with the }\end{array}$ & $\begin{array}{l}\text { Roche Molecular } \\
\text { Systems }\end{array}$ & Real-time PCR, (5'UTR) & FDA, CE & $\begin{array}{l}25 \text { to } \\
3.91 \times 10^{8}\end{array}$ & 25 & 20 \\
\hline Abbott RealTime HCV Test & Abbott Diagnostics & Real-time PCR, (5'UTR) & FDA, CE & $\begin{array}{l}12 \text { to } \\
1.00 \times 10^{8}[27]\end{array}$ & 12 & 12 \\
\hline Versant HCV RNA Test, 1.0 (kPCR) & Siemens & Real-time PCR, (pol gene) & CE & $\begin{array}{l}15 \text { to } \\
1.00 \times 10^{8}\end{array}$ & 15 & 15 \\
\hline Artus Hepatitis C Test (QS-RGQ) & Qiagen & $\begin{array}{l}\text { Real-time PCR (target } \\
\text { proprietary) }\end{array}$ & CE & $\begin{array}{l}65 \text { to } \\
1 \times 10^{6}[9]\end{array}$ & 35 & 21 \\
\hline
\end{tabular}

IVD: In vitro diagnostic. LLOQ: Lower limit of quantification. LLOD: Lower limit of detection (also referred to as analytical sensitivity). PCR: polymerase chain reaction. FDA: Food and Drug Administration. CE: European Community. HCV: Hepatitis C virus.

* LLOD shown is the overall analytical sensitivity, the LLOD by genotype and by matrix (plasma vs. serum) may be lower than the number shown.

The Versant HCV RNA 1.0 test (Siemens Healthcare) is a real-time PCR assay that uses a magnetic silica bead-based automated RNA extraction followed by automated amplification of the HCV genome and detection on the Versant Kinetic PCR (kPCR) Molecular System platform. This test replaces the quantitative, branched DNA (bDNA)-based, signal amplification test as well as the qualitative TMA-based test [8].

The Artus Hepatitis C QS-RGQ assay is a real-time PCR assay that uses a magnetic particle-based automated RNA extraction on the QIAsymphony SP platform (Qiagen) followed by amplification of the $\mathrm{HCV}$ genome and detection on the Rotor-Gene Q platform [9].

Other molecular methods that are used in management of $\mathrm{CHC}$ patients include genotyping tests (for HCV genotypes 1-6), which help determine the type and duration of treatment as well as to predict treatment outcomes. Currently, $\mathrm{HCV}$ genotyping tests use direct DNA sequencing (e.g. THE TRUGENE ${ }^{\circledR}$ HCV Genotyping Assay, Siemens Erlangen, Germany) and bi-directional sequences where genotype and subtype characterization is determined by two fluorescently labeled DNA primers or a line probe assay (INNO-LiPA HCV II Genotype Test, Innogenetics, Ghent, Belgium), that simultaneously detects of $5^{\prime}$ UTR and Core regions to improve genotype 1 characterization using a linear probe array [10].

Several real-time PCR-based non-IVD Tests (e.g. GenMark) are used and more recently the Abbott HCV Genotype Test is currently available as the only FDAapproved test. In a recent report, the Abbott $\mathrm{HCV}$ Genotype Test (Abbott Molecular) has been found to be useful for characterizing genotype 2-6 but may require a confirmatory method for correct genotype 1 characterization $[11,12]$

\section{Non-molecular methods}

$\mathrm{HCV}$ core antigen serology tests have been proposed for the use in either on-treatment monitoring or for assessing
SVR, but this application may miss approximately half of the samples $<2,000 \mathrm{IU} / \mathrm{mL}$ by PCR and may only be reliable in results $>6,000 \mathrm{IU} / \mathrm{mL}$ [13]. Therefore, $\mathrm{HCV}$ core antigen may not be suitable for detecting an active $\mathrm{HCV}$ infection. Unlike HCV core antigen tests, the clinical utility of using HCV RNA PCR-based tests in managing $\mathrm{CHC}$ patients is well established [14].

\section{Treatment landscape; past, present, and future:}

After a decade of using PEG2 $\alpha / \mathrm{RBV}$ to treat $\mathrm{CHC}$ patients, boceprevir (VICTRELIS ${ }^{\circledR}$, Merck \& Co., Inc., Whitehouse Station, NJ) and telaprevir (INCIVEK ${ }^{\circledR}$, Vertex Pharmaceuticals Incorporated Cambridge, MA), NS3/4A protease inhibitors, co-administered with PEG2 $\alpha /$ RBV were approved for HCV genotype 1 infected patients in 2011 after demonstrating significant improvements in SVR rates.

Recently, at the end of 2013, two more drugs were approved demonstrating even greater improvements in SVR rates. Simeprevir (OLYSIO ${ }^{\mathrm{TM}}$, Janssen Therapeutics, Titusville, NJ) a NS3/4A protease inhibitor $[15,16]$ and Sofosbuvir (SOVALDI ${ }^{\mathrm{TM}}$, Gilead Sciences, Inc., Foster City $\mathrm{CA}$ ) a potent $\mathrm{HCV}$ nucleotide analog NS5B polymerase inhibitor are now available [15].

Simeprevir (plus PEG2 $\alpha /$ RBV) was approved for HCV genotype 1 infected subjects with compensated liver disease (including cirrhosis) along with a screening requirement for patients with HCV genotype 1a infections for the presence of the NS3 Q80K polymorphism (in which case this therapy is not recommended).

Sofosbuvir represents the first all oral, interferon free DAA-containing regimen (combined with RBV) and the first DAA-interferon-free regimen approved for treating patients with HCV genotype 2 or 3 infections $[17,18]$. Sofosbuvir (plus RBV) has a shorter treatment duration for genotype 2 (12 weeks) than genotype 3 (24 weeks). HCV genotypes 1 or 4 infections can also be treated with 
sofosbuvir but require coadministration of PEGa/RBV for 12 weeks.

The AASLD/IDSA recommendations for testing, managing, and treating HCV were updated in 2014 in response to the changing landscape of $\mathrm{HCV}$ treatment options [19].

\section{HCV RNA Test results \& interpretations}

A definition and description of terms used to describe HCV RNA levels is provided (Table 2) and HCV RNA VL results and interpretations are described (Table 3).

To note, if HCV RNA is detected by PCR (and lower than the linear range of the test), the result is reported by the software as "HCV RNA, detected less than the Lower Limit of Quantitation (LLOQ)", even if the actual VL titer is below the sensitivity or Limit Of Detection (LOD) of the test. Being able to "detect" HCV RNA that is below the LOD of the test may seem counterintuitive since it is typically presumed that if the actual $\mathrm{HCV}$ RNA titer is below the LOD then there is nothing there to "detect".

However, the LOD is defined and calculated by the tests ability to detect HCV RNA $\geq 95 \%$ of the time. This means that even at HCV RNA titers that are half the LOD, the PCR amplification may still detect HCV RNA $\sim 50 \%$ of the time, in which case, the result will be reported as "HCV RNA detected, < LLOQ" if the HCV RNA is "detected".

\section{Viral kinetics and RGT}

In patients treated with $\mathrm{PEG \alpha} / \mathrm{RBV}$, the best predictor of an SVR was shown to be a rapid on-treatment HCV RNA decline to "undetectable" early in therapy [20]. To this end, a rapid virological response (RVR), or "undetectable" (e.g. $<50 \mathrm{IU} / \mathrm{mL})$ by 4 weeks of PEG $\alpha / \mathrm{RBV}$, has been used to determine eligibility for shortening therapy (e.g. 24 weeks versus 48 weeks, genotype 1).

New definitions for an "undetectable" HCV RNA VL

While the goal of treating $\mathrm{CHC}$ patients is to eradicate the infection as measured by an "undetectable" HCV RNA result, "undetectable" has evolved alongside the treatment algorithm. For PEGa/RBV therapy, an "undetectable" result was any result that is $<50 \mathrm{IU} / \mathrm{mL}$ (Table 4).

In contrast, for PEG $\alpha / R B V+$ boceprevir or telaprevir regimens, the term "undetectable" was defined as a "target not detected" result, which was required for patients to be eligible for shorten therapy; but for SVR assessments, a “<25 IU/mL, HCV RNA detected" was an acceptable endpoint.

For the recently approved regimen containing simeprevir, a stopping rule "cutoff" of $25 \mathrm{IU} / \mathrm{mL}$ is used at 4, 12, or 24 weeks in which all therapies are discontinued if HCV RNA

Table 2 Definitions of key analytical performance terms used in defining hepatitis C virus RNA VL titer measurements based on guidelines [28]

\begin{tabular}{ll}
\hline Result & \multicolumn{1}{c}{ Definition } \\
\hline Target not detect & HCV RNA is not detected, no observable PCR amplification or detection \\
LLOQ & Lowest HCV RNA titer within the test's dynamic range that is quantifiable and accurate \\
LOD & Lowest amount of analyte in a sample that can be detected (e.g. Detection of HCV RNA $\geq 95 \%$ by Hit Rate or PROBIT analysis) \\
ULOQ & The highest HCV RNA titer result within the test's dynamic range that is quantifiable and accurate \\
\hline
\end{tabular}

HCV: Hepatitis C virus. LLOQ: Lower limit of quantification, LOD: Limit of detection (also referred to as "analytical sensitivity"). ULOQ: Upper limit of quantification

Table 3 The results and interpretations that are reported by manufacturers of commercial hepatitis C virus RNA VL tests

\begin{tabular}{|c|c|c|}
\hline Titer result (IU/mL) & Reported results & Results interpretation* \\
\hline $\begin{array}{l}\text { "Target not detected" or } \\
\text { "Not detected" }\end{array}$ & $\begin{array}{l}\text { Results are reported as "HCV RNA not } \\
\text { detected". }\end{array}$ & $\begin{array}{l}\text { Ct value for HCV is above the limit for the assay or no Ct value for } \mathrm{HCV} \text { is } \\
\text { obtained. }\end{array}$ \\
\hline $\begin{array}{l}\text { Less than the Lower Limit } \\
\text { of Quantification (LLOQ) }\end{array}$ & $\begin{array}{l}\text { Results are reported as "HCV RNA } \\
\text { detected, less than [LLOQ] IU/mL HCV } \\
\text { RNA". }\end{array}$ & Calculated $\mathrm{IU} / \mathrm{mL}$ is below the dynamic range of the assay. \\
\hline $\begin{array}{l}\text { Titer is within the linear } \\
\text { range of the test }\end{array}$ & $\begin{array}{l}\text { Results are reported as "[number] } \\
\text { IU/mL, HCV RNA detected". }\end{array}$ & $\begin{array}{l}\text { Calculated results are quantifiable within the dynamic range of the test (e } \\
\text { g.greater than or equal to the LLOQ and less than or equal to ULOQ, } \\
\text { results) }\end{array}$ \\
\hline $\begin{array}{l}\text { Greater than the upper } \\
\text { limit of quantification } \\
\text { (ULOQ) }\end{array}$ & $\begin{array}{l}\text { Results are reported as "greater than } \\
\text { [ULOQ] IU/mL HCV RNA". }\end{array}$ & Calculated results are above the dynamic range of the assay. \\
\hline
\end{tabular}

* $\mathrm{Ct}=$ crossing point or crossing threshold, the value in which the PCR amplification is detected (sigmoidal curve) HCV: Hepatitis C virus. LLOQ: Lower limit of quantification. ULOQ: Upper limit of quantification. 
Table 4 Comparison of therapies and key clinical decisions using hepatitis C virus RNA VL

\begin{tabular}{|c|c|c|c|c|c|c|}
\hline \multirow{2}{*}{$\begin{array}{l}\text { Antiviral } \\
\text { therapy }\end{array}$} & \multirow{2}{*}{$\begin{array}{l}\text { Geno- } \\
\text { type }\end{array}$} & \multicolumn{4}{|c|}{ Response guided therapy } & \multirow{2}{*}{$\begin{array}{l}\text { Definition of "undetectable" HCV } \\
\text { RNA result to assess SVR (IU/mL) }\end{array}$} \\
\hline & & $\begin{array}{l}\text { On-therapy } \\
\text { decision? }\end{array}$ & $\begin{array}{l}\text { Responder time } \\
\text { point (weeks) }\end{array}$ & $\begin{array}{l}\text { HCV RNA result considered } \\
\text { "undetectable" } †\end{array}$ & $\begin{array}{c}\text { Treatment } \\
\text { duration } \\
\text { (weeks) }\end{array}$ & \\
\hline $\begin{array}{l}\text { PEG } \alpha / \\
\text { RBV }\end{array}$ & $1-6$ & YES & 4 or 12 & $\begin{array}{l}\text { week } 4,(\text { RVR) }<50 \mathrm{IU} / \mathrm{mL} \text { or week } 12, \\
\text { (partial responder) } 2 \log _{10} \text { drop }\end{array}$ & 24,48 , or 72 & $<50$ \\
\hline $\begin{array}{l}\text { PEG } \alpha / \\
\text { RBV } \\
+ \text { TVR }\end{array}$ & 1 & YES & 4 and 12 & TND, both RGT timepoints & 24 or 48 & $<25$ \\
\hline $\begin{array}{l}\text { PEG } \alpha / \\
\text { RBV } \\
+ \text { BOC }\end{array}$ & 1 & YES & 8 and $16^{* *}$ & TND, both RGT timepoints & 28,36 , or 48 & $<25$ \\
\hline $\begin{array}{l}\text { PEG } \alpha / \\
\text { RBV } \\
+ \text { SIM }\end{array}$ & 1 & YES* $^{*}$ & 12 & $<25 \mathrm{IU} / \mathrm{mL}$ & 24 or 48 & $<25$ \\
\hline $\begin{array}{l}\text { PEG } \alpha / \\
\text { RBV } \\
+ \text { SOF }\end{array}$ & 1 & N/A & N/A & N/A & 12 & $<25$ \\
\hline SOF/RBV & 2,3 & $\mathrm{~N} / \mathrm{A}$ & N/A & $\mathrm{N} / \mathrm{A}$ & 12 or 24 & $<25$ \\
\hline
\end{tabular}

* Fixed duration regimen, HCV RNA VL $\geq 25 \mathrm{IU} / \mathrm{mL}$ is a stopping rule.

** with a 4 week lead-in (PEG $\alpha /$ RBV)

† The test used was the $\operatorname{COBAS}^{\circledR}$ TaqMan $^{\circledR}$ for Use with the High Pure System (LLOQ $=25 \mathrm{IU} / \mathrm{mL}$, overall LOD $=20 \mathrm{IU} / \mathrm{mL}$ )

HCV: Hepatitis C virus. SVR: Sustained virologic response. PEG $\alpha$ : Pegylated interferon alpha. RBV: ribavirin. RVR: Rapid virological response. TVR: Telaprevir. TND: Target not detected. RGT: Response guided therapy. BOC: boceprevir. SIM: Simeprevir. SOF: Sofosbuvir.

results are above this cutoff (Table 4). For sofosbuvir, HCV RNA testing is only recommended after treatment after a fixed duration and to assess SVR. Both regimens use " $<25$ $\mathrm{IU} / \mathrm{mL}, \mathrm{HCV}$ RNA detected" for defining "undetectable".

In the "real world setting" it is likely that there will be less patient compliance than in the clinical trials. Therefore, it may be useful to investigate whether HCV RNA VL "adherence monitoring" on-therapy is worthwhile in patients suspected of noncompliance, especially when considering the high treatment costs.

Given that the trials used a test with a LLOQ of 25 $\mathrm{IU} / \mathrm{mL}$, differences in a tests LLoQ is important. How should clinicians handle a quantifiable result of $22 \mathrm{IU} /$ $\mathrm{mL}$ derived from a different test than the one used in the clinical trials (e.g. one that has a lower LLOQ)? These are practical considerations that may cause uncertainty for clinicians.

\section{Using "target not detected" for shortening therapy}

With the introduction of boceprevir and telaprevir, new RGT rules were introduced which lead to considerable confusion in the terms used to define "undetectable" and when to apply this interpretation. These rules were based on a re-analysis of the boceprevir and telaprevir trials data that was published by the FDA where it was concluded that a "HCV RNA detectable, <LLOQ" result predicted a significantly lower cure rate compared with subjects with an "undetectable" ("Target Not Detected") result [21]. Based on this analysis, it was determined that a confirmed "detectable but below the LLOQ" HCV RNA result should not be considered equivalent to an "undetectable" HCV RNA ("Target Not Detected") result for the purposes of RGT. Therefore, a "Target Not Detected" result at both 4 and 12 weeks of PEG $\alpha /$ RBV + telaprevir therapy was required to shorten therapy ( 48 weeks to 24 or 36 weeks of PEG $\alpha /$ RBV). To further add complexity, stopping rules were also different for boceprevir and telaprevir regimens (100 and 1,000 IU/mL, respectively).

Differences between HCV RNA assays with DAA therapies

Although all commonly used HCV RNA assays report the results in the standardized $\mathrm{IU} / \mathrm{mL}$, not all tests perform similarly. Several reports have demonstrated differences between how assays report results, particularly in detecting low amounts of HCV RNA [22,23].

In these studies, concordance analyses have determined that HCV RNA differences in reporting results that are "Target Not Detected" versus "HCV RNA detected, < LLOQ" have become apparent.

This is particularly true in one study that investigated results generated from the TaqMan ${ }^{\circledR}$ HCV Test, v2.0 used as part of a phase III clinical trial with simeprevir plus PEGa/RBV and compared it to Abbott RealTime HCV Test [24]. Overall, there was good agreement between the 2 assays; however, a large number of samples (26\%-35\%) at week 4 of treatment had detectable HCV RNA levels $(<L L O Q)$ with the Abbott RealTime assay that were "Target Not Detected" by the HPS-TaqMan ${ }^{\circledR} \mathrm{HCV}$ Test, v2.0. These patients received shortened therapy based on the HPS-TaqMan ${ }^{\circledR}$ HCV Test, v2.0 TND result and high SVR rates were achieved. Thus, if the Abbott 
Table 5 Summary of phase 3 trials of sofosbuvir and ledipasvir in hepatitis C virus genotype 1

\begin{tabular}{|c|c|c|c|}
\hline Study & Population & Treatment/Duration & SVR12 rates \\
\hline \multirow[t]{4}{*}{ ION-1 } & HCV GT1 treatment-naïve including $15.7 \%$ (136/865) with cirrhosis & SOF/LDV, 12 weeks & $97.7 \%(209 / 214)$ \\
\hline & & SOF/LDV + RBV, 12 weeks & $97.2 \%(211 / 217)$ \\
\hline & & SOF/LDV, 24 weeks & $N A(n=217)$ \\
\hline & & SOF/LDV + RBV, 24 weeks & $N A(n=217)$ \\
\hline \multirow[t]{4}{*}{ ION-2 } & HCV GT 1 treatment-experienced including 20.0\% (88/440) with cirrhosis & SOF/LDV, 12 weeks & $93.6 \%(102 / 109)$ \\
\hline & & SOF/LDV+RBV, 12 weeks & $96.4 \%(107 / 111)$ \\
\hline & & SOF/LDV, 24 weeks & $99.1 \%(108 / 109)$ \\
\hline & & SOF/LDV+RBV, 24 weeks & $99.1 \%(110 / 111)$ \\
\hline \multirow[t]{3}{*}{ ION-3 } & HCV GT1 treatment-naïve & SOF/LDV, 8 weeks & $94.0 \%(202 / 215)$ \\
\hline & & SOF/LDV + RBV, 8 weeks & $93.1 \%(201 / 216)$ \\
\hline & & SOF/LDV, 12 weeks & $95.4 \%(206 / 216)$ \\
\hline
\end{tabular}

SVR: Sustained virologic response. HCV: Hepatitis C virus. GT: Genotype. SOF: Sofosbuvir. LDV: ledipasvir. RBV: ribavirin. NA: not available.

RealTime assay results at week 4 of therapy had been used to determine treatment duration, these patients may have been over-treated by an additional 6 months.

Since these DAA-containing triple therapy requires HCV RNA to be TND at both weeks 4 and 12 in order to shorten therapy, differences between HCV RNA assays can affect key medical decisions, in this case resulting in a larger portion of patients treated for longer durations (if the same cutoffs are used). It was therefore suggested that a cutoff of $<12 \mathrm{IU} / \mathrm{mL}$ (detected) may be appropriate for the Abbott RealTime HCV Test. However, since this cutoff has not yet been clinically validated and further studies are needed.

While boceprevir and telaprevir containing regimens have been replaced by more potent regimens, differences in the performance of HCV RNA tests might be of importance, particularly if they are not clinically validated.

Therapies expected in the near future

Faldaprevir is a HCV protease inhibitor in late stage phase 3 clinical trials and administered once daily is being tested in combination with PEGa/RBV, and in IFN-free regimens with other DAA agents.
Sofosbuvir is also being investigated in combination with antiviral agents that target different virus proteins such as daclatasvir and ledipasvir (nonstructural protein 5A [NS5A] inhibitors), with or without RBV [25]. Preliminary results of Phase 3 trials of the interferon-free sofosbuvir and ledipasvir combination regimen in patients with HCV genotype 1 infection have shown SVR12 rates of 93\%-99\% (Table 5).

Abbvie is evaluating an interferon-free 3-DAA combination regimen containing the $\mathrm{ABT}-450$, ritonavir, and ABT-267 co-formulated tablet (ABT-450/r/ABT-267) and ABT-333 tablet administered with or without RBV. ABT-450 is a NS3A protease inhibitor; ABT-267 is a NS5A inhibitor; and ABT-333 is a non-nucleoside inhibitor of the NS5B polymerase. This 3-DAAs regimen with and without RBV has reported SVR12 rates of $90 \%-100 \%$ in a phase 2 trial of patients infected with HCV genotype 1 [26]. Preliminary results of Phase 3 trials of this 3-DAA regimen have shown very high SVR12 across different HCV genotype 1 infected patient populations (Table 6).

Table 6 Summary of phase 3 trials of ABT-450/r/ABT-267, ABT-333 plus ribavirin in hepatitis C virus genotype 1

\begin{tabular}{|c|c|c|c|}
\hline Study & Population & Treatment/Duration & $\mathrm{SVR}_{12}$ \\
\hline \multirow[t]{2}{*}{ PEARL-II } & GT1b treatment-experienced $(\mathrm{N}=179)$ & 3-DAA + RBV, 12 weeks $(n=88)$ & $97 \%(85 / 88)$ \\
\hline & & 3-DAA only, 12 weeks $(n=91)$ & $100 \%(91 / 91)$ \\
\hline \multirow[t]{2}{*}{ PEARL-III } & GT1b treatment-naive $(\mathrm{N}=419)$ & 3-DAA + RBV, 12 weeks $(n=210)$ & $99 \%(209 / 210)$ \\
\hline & & 3-DAA only, 12 weeks $(n=209)$ & $99 \%(207 / 209)$ \\
\hline \multirow[t]{2}{*}{ PEARL-IV } & GT1a treatment-naive $(\mathrm{N}=305)$ & 3-DAA + RBV, 12 weeks $(n=100)$ & $97 \%(97 / 100)$ \\
\hline & & 3-DAA only, 12 weeks $(n=205)$ & $90 \%(185 / 205)$ \\
\hline \multirow[t]{2}{*}{ TURQUOISE-II } & $\begin{array}{l}\text { GT1 treatment-naive and treatment-experienced with } \\
\text { compensated cirrhosis }(N=380)\end{array}$ & 3-DAA + RBV, 12 weeks $(n=208)$ & $92 \%(191 / 208)$ \\
\hline & & 3-DAA + RBV, 24 weeks $(n=172)$ & $96 \%(165 / 172)$ \\
\hline SAPPHIRE-I & GT1 treatment-naive $(\mathrm{N}=631)$ & 3-DAA + RBV, 12 weeks $(n=473)$ & $96 \%(455 / 473)$ \\
\hline SAPPHIRE-II & GT1 treatment-experienced $(\mathrm{N}=394)$ & 3-DAA + RBV, 12 weeks $(n=297)$ & $96 \%(286 / 297)$ \\
\hline
\end{tabular}

SVR: Sustained virologic response. GT: Genotype. DAA: Direct acting antivirals. RBV: ribavirin. 


\section{Future directions}

Given the global burden of $\mathrm{CHC}$ and the advent of newer, more potent regimens with higher cure rates, increasing screening to identify at-risk $\mathrm{CHC}$ patients and linking them to care is even more important. New guidelines that support screening are important but linkage to care is an ongoing global challenge.

With the first DAA-containing regimens, clinical decisions based on HCV RNA VL results (and new interpretations) created complexity for the laboratory and clinician. Further, tests were shown to perform differently in some of DAA-containing regimens. Therefore, additional testing with each new DAA containing regimen across various commercially available HCV RNA tests is important.

While the new interferon-free therapies have demonstrated greater efficacy, accurate HCV RNA quantification remains important. In addition, interferon-free regimens may have fixed durations, but on-therapy "adherence monitoring" may be helpful, particularly given the high cost of the new regimens. Therefore, for these and other reasons discussed here, measuring $\mathrm{HCV}$ RNA will likely continue to be important.

\section{List of abbreviations}

CHC: chronic hepatitis C; CLIA: Clinical Laboratory Improvements Amendment; DAA: direct acting antivirals; HCC: hepatocellular carcinoma; HCV: hepatitis C virus; IU: international units; LLOD: lower limit of detection; LLOQ: lower limit of quantitation; LOD: limit of detection; NAT: nucleic acid amplification; NS5A: nonstructural protein 5A; PCR: polymerase chain reaction; PEGa/RBV: pegylated-interferon/ribavirin; RGT: response-guided therapy; RVR: rapid virological response; SVR: sustained virologic response; ULOQ: upper limit of quantitation; TMA: transcription mediated amplification.

\section{Competing interests}

Bryan Cobb is an employee of Roche Molecular Systems Inc.

Regis A. Vilchez is an employee of Abbvie

\section{Authors' contributions}

$\mathrm{BC}, \mathrm{GH}$ and RV contributed to the data analysis and manuscript writing.

\section{Acknowledgements}

The authors thank Gary Witherell, Ph.D. (InClin Inc.) for medical writing support.

\section{Declarations}

B. Cobb and G. Heilek are employees of Roche and provided a sponsorship for this supplement. COBAS TagMan tests referred here were developed by Roche. Vilchez is an employee of Abbvie and has not provided a sponsorship for this supplement.

This article has been published as part of BMC Infectious Diseases Volume 14 Supplement 5, 2014: Proceedings of the Third Workshop of the HCV Study Group in the Calabria Region: Results from the South Italian Network for Rational Guidelines and International Epidemiology (SINERGIE) Project. The full contents of the supplement are available online at http://www. biomedcentral.com/bmcinfectdis/supplements/14/S5.

\section{Authors' details}

'Roche Molecular Systems Inc., Pleasanton, California, USA. ${ }^{2}$ Abbvie, Chicago, Illinois, USA.

Published: 5 September 2014
References

1. Lavachy D: Evolving epidemiology of hepatitis C virus. Clin Microbiol Infect 2011, 17:107-115.

2. Smith BD, Morgan RL, Beckett GA, Falck-Ytter $Y$, Holtzman D, Teo CG, Jewett A, Baack B, Rein DB, Patel N, Alter M, Yartel A, Ward JW, Centers for Disease Control and Prevention: Recommendations for the identification of chronic hepatitis $C$ virus infection among persons born during 19451965. MMWR Recomm Rep 2012, 61(RR-4):1-32, Erratum in: MMWR Recomm Rep 2012, 61:886.

3. Centers for Disease Control and Prevention (CDC): Testing for HCV infection: an update of guidance for clinicians and laboratorians. MMWR Morb Mortal Wkly Rep 2013, 62:362-365.

4. Mutimer D, Aghemo A, Diepolder H, Negro F, Robaeys G, Ryder S, Zoulim F, Peck M, Craxi A, Fried M, Zeuzem S: EASL Clinical Practice Guidelines: management of hepatitis C virus infection. J Hepatol 2014, 60:392-420.

5. Chevaliez S1, Bouvier-Alias M, Rodriguez C, Soulier A, Poveda JD, Pawlotsky JM: The Cobas AmpliPrep/Cobas TaqMan HCV test, version 2.0, real-time PCR assay accurately quantifies hepatitis $C$ virus genotype 4 RNA. J Clin Microbiol 2013, 51:1078-1082.

6. Zitzer H, Heilek G, Truchon K, Susser S, Vermehren J, Sizmann D, Cobb B, Sarrazin C: Second-generation Cobas AmpliPrep/Cobas TaqMan HCV quantitative test for VL monitoring: a novel dual-probe assay design. J Clin Microbiol 2013, 51:571-577.

7. Abbott RealTime HCV. Des Plaines, IL: Abbott Laboratories; 2011, May [package insert].

8. VERSANT ${ }^{\mathbb{R}}$ HCV RNA 1.0 Assay (kPCR). Tarrytown, NY: Siemens Healthcare Diagnostics Inci iCE mark certification].

9. Artus Hepatitis C QS-RGQ assay. Hilden, Germany; Qiagen; [CE mark certification].

10. Bouchardeau F, Cantaloube JF, Chevaliez S, Portal C, Razer A, Lefrère JJ, Pawlotsky JM, De Micco P, Laperche S: Improvement of hepatitis C virus (HCV) genotype determination with the new version of the INNO-LiPA HCV assay. J Clin Microbiol 2007, 45:1140-1145.

11. Mallory MA, Luxic DX, Sears MT, Cloherty GA, Hillyard DR: Evaluation of the

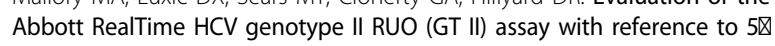
UTR, core and NS5B sequencing. J Clin Micro .

12. González V, Gomes-Fernandes M, Bascuñana E, Casanovas S, Saludes V, Jordana-Lluch E, Matas L, Ausina V, Martró E: Accuracy of a commercially available assay for HCV genotyping and subtyping in the clinical practice. J Clin Virol 2013, 58:249-253.

13. Miedouge M, Saune K, Kamar N, Rieu M, Rostaing L, Izopet J: Analytical evaluation of HCV core antigen and interest for HCV screening in haemodialysis patients. J Clin Virol 2010, 48:18-21.

14. Ghany MG, Strader DB, Thomas DL, Seeff LB: Diagnosis, management, and treatment of hepatitis C: an update. Hepatology 2009, 49:1335-1374.

15. Simeprevir (OLYSIO ${ }^{\mathrm{TM}}$ ). Titusville NJ: Janssen Therapeutics; 2013, [package insert].

16. Asselah T, Marcellin P: Second-wave IFN-based triple therapy for HCV genotype 1 infection: simeprevir, faldaprevir and sofosbuvir. Liver Int 2014, 34(Suppl 1):60-68.

17. Jacobson IM, Gordon SC, Kowdley KV, Yoshida EM, Rodriguez-Torres M, Sulkowski MS, Shiffman ML, Lawitz E, Everson G, Bennett M, Schiff E, AlAssi MT, Subramanian GM, An D, Lin M, McNally J, Brainard D, Symonds WT, McHutchison JG, Patel K, Feld J, Pianko S, Nelson DR, POSITRON Study; FUSION Study: Sofosbuvir for hepatitis C genotype 2 or 3 in patients without treatment options. N Engl J Med 2013, 368:1867-1877.

18. Sofosbuvir (SOVALDITM). Foster City CA: Gilead Sciences, Inc; 2013, [package insert].

19. Recommendations for Testing, Managing, and Treating Hepatitis $C$ [http://www.hcvguidelines.org/sites/default/files/full_report.pdf].

20. Poordad FF: Review article: the role of rapid virological response in determining treatment duration for chronic hepatitis $C$. Aliment Pharmacol Ther 2010, 31:1251-67.

21. Harrington PR, Zeng W, Naeger LK: Clinical relevance of detectable but not quantifiable hepatitis $C$ virus RNA during boceprevir or telaprevir treatment. Hepatology 2012, 55:1048-1057.

22. Vermehren J, Aghemo A, Falconer K, Susser S, Lunghi G, Zeuzem S, Colombo M, Weiland O, Sarrazin C: Clinical significance of residual viremia detected by two real-time PCR assays for response-guided therapy of HCV genotype 1 infection. J Hepatol 2014, Jan 11 
23. Peiffer $\mathrm{KH}$, Sarrazin $\mathrm{C}$ : The importance of HCV RNA measurement for tailoring treatment duration. Dig Liver Dis 2013, 45(Suppl 5):S323-31.

24. Vermehren J, Kau A, Gärtner BC, Göbel R, Zeuzem S, Sarrazin C: Differences between two real-time PCR-based hepatitis $C$ virus $(\mathrm{HCV})$ assays (RealTime HCV and Cobas AmpliPrep/Cobas TaqMan) and one signal amplification assay (Versant HCV RNA 3.0) for RNA detection and quantification. J Clin Microbiol 2008, 46:3880-3891.

25. Schinazi R, Halfon P, Marcellin P, Asselah T: HCV direct-acting antiviral agents: the best interferon-free combinations. Liver Int 2014, 34(Suppl 1):69-78

26. Kowdley KV, Lawitz E, Poordad F, Cohen DE, Nelson DR, Zeuzem S, Everson GT, Kwo P, Foster GR, Sulkowski MS, Xie W, Pilot-Matias T, Liossis G, Larsen $L$, Khatri A, Podsadecki T, Bernstein B: Phase $2 \mathrm{~b}$ trial of interferonfree therapy for hepatitis C virus genotype 1. N Engl J Med 2014, 370:222-32.

27. Drexler JF, Reber U, Wuttkopf A, Eis-Hübinger AM, Drosten C: Performance of the novel Qiagen artus QS-RGQ viral load assays compared to that of the Abbott RealTime system with genetically diversified HIV and hepatitis C Virus plasma specimens. J Clin Microbiol 2012, 50:2114-7.

28. Clinical and Laboratory Standards Institute: Protocols for Determination of Limits of Detection and Limits of Quantitation, Approved Guideline. CLSI document EP17-A (ISBN 1-56238-551-8) Wayne, PA; 2004.

doi:10.1186/1471-2334-14-S5-S8

Cite this article as: Cobb et al:: Molecular diagnostics in the management of chronic hepatitis C: key considerations in the era of new antiviral therapies. BMC Infectious Diseases 2014 14(Suppl 5):S8.

\section{Submit your next manuscript to BioMed Central and take full advantage of:}

- Convenient online submission

- Thorough peer review

- No space constraints or color figure charges

- Immediate publication on acceptance

- Inclusion in PubMed, CAS, Scopus and Google Scholar

- Research which is freely available for redistribution

Submit your manuscript at www.biomedcentral.com/submit 